This item was submitted to Loughborough's Research Repository by the author.

Items in Figshare are protected by copyright, with all rights reserved, unless otherwise indicated.

\title{
Evoking the female 'Asexual': Narrating the silenced self
}

PLEASE CITE THE PUBLISHED VERSION

https://doi.org/10.1080/14484528.2018.1510288

PUBLISHER

(c) Taylor and Francis

VERSION

AM (Accepted Manuscript)

PUBLISHER STATEMENT

This is an Accepted Manuscript of an article published by Taylor \& Francis in Life Writing on 14 September 2018, available online: http://www.tandfonline.com/10.1080/14484528.2018.1510288.

\section{LICENCE}

CC BY-NC-ND 4.0

\section{REPOSITORY RECORD}

Sadlier, Aoife. 2018. "Evoking the Female 'asexual': Narrating the Silenced Self". figshare. https://hdl.handle.net/2134/37042. 
Title: Evoking the female 'asexual': narrating the silenced self

Author's name: Dr Aoife Sadlier

Institutional affiliation (current): Room 2.07b, Sir John Beckwith Centre for Sport, School of Sport, Exercise and Health Sciences, Loughborough University, LE11 3TU, United Kingdom.

Correspondence email: A.C.Sadlier@lboro.ac.uk

This work formed part of a PhD that was obtained in the Department of Culture, Media and Creative Industries, King's College London, in April 2017. This

research was generously funded by the Economic and Social Research Council of Great Britain (ESRC) from September 2013 to March 2017.

Section for submission: Reflections

Evoking the female 'asexual:' narrating the silenced self 


\begin{abstract}
In the twenty-first century, asexuality is defined as a 'lack' of sexual attraction. This definition is problematic as it erodes individual idiosyncrasies, assumes that everybody is sexual and that sexuality is immutable. At this juncture, a study of female (a)sexualities is long overdue. Until recently, Myra T. Johnson's chapter on asexual and autoerotic women was perhaps the only piece written on this subject. She highlighted the dangers of reducing asexual-identified women to symbols of spiritual devotion or political consciousness at the absence of examining their lived realities, a concern that still resonates.
\end{abstract}

In this piece of performative writing, which speaks to Nguyen's 'me-search,' I seek to invoke the lost voice of the female asexual by weaving queer and feminist theories of sexuality with my self-narrative, which explores my journey from asexuality to autoeroticism. Drawing on Ahmed's 'queer phenomenology,' which reconceptualises sexual orientation as the lived body's relationship with time and space, I posit asexuality as a re-oriented queer sensibility. Traversing key scenes from my trajectory, I seek to convey silences, ambivalences, transitions and becomings, thus highlighting the elusiveness of identity categories.

Ultimately, I wish to address Johnson's vision by narrating the lived realities of female (a)sexualities, beyond representations.

Keywords: Me-search; Performance Autoethnography; Asexuality; Autoeroticism; Dance; Identity politics.

\title{
Introduction
}


In the introduction to her novel, Sexing the Cherry, Jeanette Winterson (2014, viiviii) asserts that: 'I am interested in the holes. The string is the narrative but the spaces are what matters.' Winterson argues that one of the greatest lies we are told as human beings is that our lives are linear narratives, punctuated by events that should be experienced at appropriate life stages. She encourages us to engage with the slippage between memory and experience, and to explore our various genealogies of self across time, space and historical context, an approach that this reflexive piece harnesses.

Winterson's approach is relevant to the discipline of life writing, which involves the recording of experiences through genres such as autobiography, diaries, personal testimonies and letters, and has become increasingly engaged with postcolonial and feminist theory (McCooey 2017). McCooey (ibid: 277) asserts that life writing is concerned with 'the limits between literary and factual writing, between narrative as a literary device and narrative as lived experience; and between autobiography and fiction.' I argue that these limits need to be further explored through an engagement with performance, as a way of communicating our identities, problematising the restrictions imposed on human experience by dominant institutions, and articulating the narratives of individuals otherwise excluded from public discourses (Butler 1990, 1993). Returning to Winterson's (2014) opening quote, I argue that life writing has failed to engage fully with the holes; rather it engages with the string. This criticism is particularly relevant to the area of human sexuality, since 
heterosexuality is one of the linear narratives of 'normal' human development we are told. Yet, queer sexualities, which refer to 'nonnormative logics and organizations of community, sexual identity, embodiment, and activity in space and time' (Halberstam 2005, 6) require a more nuanced approach, which focuses on transformative moments. Queer time and space seek to develop alternative lineages 'to the institutions of family, heterosexuality and reproduction.' What life writing therefore requires is an analysis of 'the queer moments when objects slip' (Ahmed 2006, 171), so that we can parody the limitations placed on human experience, and work towards a more ethical relationship between all human beings.

In this piece of performative life writing, I evoke the lost narrative of the female asexual, by drawing on Nguyen's $(2015,469)$ 'me-search,' a methodology that acknowledges 'the intimacy between myself as subject and the subject of my scholarly work.' 1 I equally utilise Spry's (2001) account of performing ethnography, addressing her critique of the academy's disembodied approach to scholarship, by highlighting 'the body as a site of scholarly awareness and corporeal literacy' (ibid., 706). Weaving poetic language and critical selfreflexivity, this piece aims to dance around the linearity of academic prose and to enable the elaboration of 'migratory identities' (ibid.). This aim is captured in Spry's (ibid., 708) words: 'I have learned that heresy is greatly misaligned and, when put to good use, can begin a robust dance of agency in one's

\footnotetext{
${ }^{1}$ Me-search was one of the key themes of 'Talking Bodies' 2015, a biennial international interdisciplinary conference on identity, sexuality and representation, held at the University of Chester, the United Kingdom from 31 March to 02 April 2015. I performed the poetry/prose that forms the main part of this piece at this conference.
} 
personal/political/professional life.' Indeed, dance as a metaphor for an alternative vision of female (a)sexualities ${ }^{2}$ is key to this piece. I am influenced by Cixous and Clement's (1986) concept of 'the feminine libidinal economy,' which highlights the life-affirming and creative potential of the moving female body in thwarting the death drive of patriarchal structures. It is hoped that the sense of movement evoked will lead to what Spry $(2001,721)$ refers to as 'open agency,' an emerging voice unfettered by patriarchal constraints. This approach is pertinent when considering the narrative of the female 'asexual,' which has been reduced to stereotypes of frigidity and chasteness within popular, queer and feminist discourses (Cerankowski and Milks 2014).

Drawing on Ahmed's (2006) queer phenomenology, where sexuality is viewed as the lived body's relationship with time and space, this piece seeks to reconceptualise asexuality as a reoriented queer sensibility, with realigned erotic poles from autoeroticism to polyamory. In the process, it seeks to challenge the fixity of identity categories and highlight their inadequacy in narrating the complexities of lived realities. It also seeks to capture embodied moments when identities are in flux, and the sense of becoming these offer. Female (a)sexualities and indeed the category of 'woman' can therefore be viewed as dancing processes, which we can continually deconstruct and reconstruct in light of our collective dance.

\footnotetext{
2 The bracketing of the (a) and the allusion to a plurality in the word (a)sexualities are important here, as this piece seeks to challenge the fixity of identity categories and to acknowledge that women may engage with asexuality at various stages of their lives. Equally, each woman's experience of asexuality is unique. There is no universal narrative.
} 
The performance is in two acts, preceded by a prologue, where I introduce myself through the fictional character, 'the girl in the navy blue dress,' and various other voices from past and present. Each act is punctuated by a number of key scenes from my trajectory.

\section{Prologue}

[Enter the twenty-first century scholar]

[Enter the ghost of the female 'asexual']

[Enter the girl in the navy blue dress]

Act 1: The body in stasis

Scene 1: The act of disappearing

Scene 2: I got life (!)

Scene 3: June 2012 - The Postfeminist blues

Act 2: Identities in flux

Scene 1: November 2014 - Dancing at the edge of sea and sky

Scene 2: Back on land

Scene 3: Zumba: Becoming my dance

\section{Coda: Moving on}

The prologue introduces the main protagonist, while the first act explores painful passages related to body and identity, highlighting the difficulties wrought by being recognised as a woman within heteronormative spaces. This act also navigates my arrival at an asexual orientation in September 2012. The second act explores my journey from asexuality to autoeroticism, and beyond. It narrates the creative potentialities of identity in flux and the inadequacy of the 
term 'asexuality' in fully capturing the complexities of lived experiences.

Ultimately, this act highlights the power of the moving female body as a means of thwarting the destructive power of patriarchal formulations and transcending the loss associated with being at the margins of intelligibility, a theme that further emerges in the coda. Each act is comprised of various modes of writing: memories written in the third person, ${ }^{3}$ poetry and longer prose passages. The multi-modal form of address seeks to destabilise the notion of the 'I' and to look to alternative modes of navigating the idiosyncrasies of human experience. Each scene is followed by reflective notes that critically reflect upon the dynamics that dance beneath its surface.

Now, let me introduce the key protagonists in this drama.

\section{Prologue}

\section{[Enter the twenty-first century scholar]}

In the twenty-first century, asexuality has become synonymous with sexual orientation, being described by psychologists and the asexual community as a 'lack' of sexual attraction (Bogaert 2004; AVEN 20184'). This definition is problematic, as it erodes individual idiosyncrasies, assumes that everybody is sexual and that sexuality is immutable. At this juncture, a study of female (a)sexualities is long overdue. Firstly, very little has been written on the subject. Until recently, Myra T. Johnson's (1977) chapter was perhaps the only offering.

\footnotetext{
3 I use this as a distancing technique, so that I can look back on my past self with more compassion.

4 AVEN (The Asexuality Visibility and Education Network), 2018. Available at: http://www.asexuality.org [last accessed 12 April 2018].
} 
Secondly, the socio-historical context surrounding female sexuality has transformed in the last 40 years. As Gill and Scharff (2011) assert, with the rise of a postfeminist sensibility whereby women are represented as desiring their own sexual objectification, the possibility of new female subjectivities is being limited for all women. ${ }^{5}$ Therefore, a study of female (a)sexualities is particularly relevant to the twenty-first century. Finally, this performance focuses on women, because as Young ([1980] 2005) argues, female bodily agency is constrained within heteronormative spaces in the Western world. Although heteronormative culture is limiting for men, its effects are not as marked as for women, due to deeply ingrained patriarchal structures.

\section{[Enter the ghost of the female 'asexual']}

In 1977, Myra T. Johnson wrote the first full chapter on asexuality, with particular reference to women: 'Asexual and Autoerotic Women: Two Invisible Groups,' which appeared in Gochros and Gochros' The Sexually Oppressed (1977). Johnson distinguished between autoerotic women (who masturbate but who do not engage in sex with others) and asexual women (who engage in neither). Her work was significant, for she highlighted the dangers of reducing asexualidentified women to symbols of spiritual devotion or political consciousness, and failing to examine their lived realities. Indeed, this concern still resonates in the twenty-first century.

\footnotetext{
${ }^{5}$ In more recent work, Elias, Gill and Scharff (2017) focus on the concept of aesthetic labour, which highlights that women are increasingly encouraged to be aesthetic entrepreneurs, maintaining vigilance concerning their appearance through surveillant practices such as social media and photography.
} 
Unfortunately, in their introduction to a follow-up collection, Helping the Sexually Oppressed, Gochros, Gochros and Fisher (1986) failed to mention asexual women. Instead, they engaged in a discussion of 'abnormal' female sexuality, which they saw as a dichotomy between frigidity and promiscuity. Johnson's visionary work was ignored. The limitless voices of female (a)sexualities were silenced and disappeared. The stock character of the female asexual hid in the shadows, waiting for her curtain call.

\section{[Enter the girl in the navy blue dress]}

In September 2012, I discovered asexuality. Truthfully, I first heard the word asexual as a voice in my head. It whispered softly and then became louder. I didn't know what it meant but as I read more, I felt a sense of relief. Undoubtedly, my identification was a cumulative process. Yet it came to me in a moment of divine inspiration. Through this label I felt somehow empowered, although I was equally aware that it failed to capture my lived reality, notably my immense energy, strength, and self-containment. I often questioned why I had to identify as anything at all. I realise now that I adopted a label as a reaction against assumptions that I was heterosexual, monogamous, and wanted children.

As act one of this performance demonstrates, there are contradictions in my trajectory but it is precisely these that I wish to unpick. From an early age I have experienced discomfort with my body, ${ }^{6}$ which manifested itself in a $14 \mathrm{~kg}$ weight loss at the age of 11. I grew up in a patriarchal household, where my father commented on my mother's appearance and my mother objectified my body. I

\footnotetext{
${ }^{6}$ See Act 1 Scene 1, The Disappearing Act.
} 
could not move freely within this space. ${ }^{7}$ A sense of discomfort under the male gaze pervaded my teenage years, a concern that still resonates today. ${ }^{8}$ I was often accused of being quiet. However, if I could have mustered up the courage to speak the words that I felt, people would have been shocked at their violence. The only way I could cope was through playing music, which allowed me to express the silenced voices I held within me. Yet, when I had to perform, I would turn into a statue. My body was still in stasis and it was only when I discovered my love for the Latin dance fitness programme, Zumba Fitness, ${ }^{9}$ at the age of 24 , and in particular when I began teaching Zumba classes, at the age of 27, that I experienced a sense of catharsis. ${ }^{10}$ This is why movement and dance are so central to the flow of the following narrative.

Act two narrates a moment of becoming that took place far away: on the Caribbean island of Puerto Rico, having just presented a paper on female (a)sexualities at a conference. Through my encounter with a Puerto Rican waiter, ${ }^{11}$ my internalised view of asexuality as a fixed essence was uprooted. I have reviewed the scene of our encounter many times, trying to understand its

\footnotetext{
7 See Act 1 Scene 2, I got life (!)

${ }^{8}$ See Act 1 Scene 3, The Postfeminist Blues.

${ }^{9}$ Zumba was created by Alberto (Beto) Pérez in Colombia in the 1990s. It incorporates four core Latin rhythms (merengue, salsa, cumbia and reggaeton) and has come to include a broader range of international music styles. Interestingly, Beto's discovery of Zumba was a complete accident, as he forgot the regular CD he normally used to teach and was forced to use his salsa and merengue $\mathrm{CD}$. Yet, as he saw the smiles rippling across his class participants' faces, he realised that the feeling needed to be bottled. Beto left for the US to market his concept and in 2006 Zumba became a formal fitness programme (see Kabir forthcoming).

10 See Act 2 Scene 3, Zumba: Becoming my dance.

${ }^{11}$ See Act 2 Scene 1, November 2014 - Dancing at the edge of sea and sky.
} 
dynamics. ${ }^{12}$ Regardless of whether or not I fully understand what this experience meant for me, it transformed how I viewed my subjectivity.

In March 2015, I moved from asexuality to autoeroticism, a shift that I see as a source of my emerging bodily autonomy. ${ }^{13}$ I also began to consider the possibilities of non-sexual polyamory. These developments propelled me to engage in an ecstatic dance, which led me to abandon sexual orientation labels in October 2016. I now realise that 'asexuality' is a product of patriarchy and capitalism, both of which are systems that commodify human desires and constrain multiple forms of human expression. My desire to connect with others and to feel a sense of equilibrium beyond the fixity of labels will be reached by the coda. ${ }^{14}$

Now, let the performance truly begin.

\section{Act 1: The body in stasis}

Scene 1: The act of disappearing

[Enter the ghost of me past]

She was at playschool, aged 4. It was a day when parents had been invited in. They were all sitting in chairs. The teacher decided to put on some music so the children could get up and dance. One by one, little children's toes came to life. Eventually, all the children were up, spinning in circles and laughing. All except for her... She sat in a corner with her mother, who coaxed her to get up and move. But she would not budge. She cannot remember exactly how she felt at the time but she can only suspect that she felt paralysed and mute, as she often would in later years, when faced with similar situations.

\footnotetext{
12 See Act 2 Scene 2, Back on land and Act 2 Scene 4, Shipwrecked.

13 In Johnson's (1977) chapter, asexuality and autoeroticism were considered to be separate categories. In Johnson's synthesis, asexual women were those who did not want to engage in partnered sexual relationships or masturbation. Autoerotic women did not want to engage in partnered sex but masturbated. In the twenty-first century, autoeroticism is contained as a possibility within the label of asexuality, as more significant is the lack of sexual attraction to another person. As this article suggests however, the current definition of asexuality is limiting.

14 See the Coda, Moving On.
} 
I reflect: This is my earliest memory related to dance. As can be seen, my origins were in stillness. From a very young age, I can remember feeling incredibly uncomfortable within my own body. As a child, I was overweight. I spent a lot of time on my own and felt like a misfit in the world. I also thought that I was never good enough in the eyes of my mother. In this scene, she coaxes me, but I feel no compulsion to comply. I ask myself now if this was an act of agency. After all, why should one move if one does not feel moved?

\section{Scene 2: 'I got life' (!)}

[Enter the female 'asexual, doing her death dance]

Summer 2007. She had just finished a year of studying Music at University and was feeling bereft. The personal utopia she had built up since childhood - Classical Music as salvation - came crashing down around her. During that first year, she struggled with her emotions. She worked from first thing in the morning to late at night, competing with her flatmate, who was in the same year of her course.

She put on almost a stone.

That summer, she moved back home again. She hated herself. And ultimately she decided, as she had all those years ago, that there was something she could take control of: her weight, her body. ${ }^{15}$ She could shape its contours. This time however, the aim was mish-mashed with the pervasive thought of her flatmate's anorexia and also her reading of books about Auschwitz in preparation for her visit there that summer. Primo Levi's If This Is A Man ([1947] 2003) was her main read. Something reverberated with her past body, whose feelings and motivations she could not unearth (although she longed to).

She embarked on a mission of control.

Each day there was the same reveille. Get up at eight. Eat an apple and an orange. Drink a glass of water. Do 20 minutes of skipping. When Dad had gone to Mass, put on that one song that she played - Nina Simone's I Got Life - to which she developed her own little dance routine, which she repeated over and over again, with no variations. It was like a record on a loop, a girl dancing to a song about life, yet in reality dancing herself to death.

\footnotetext{
15 I was almost 20 years old when this scene took place. It was my second voyage into conscious weight-loss. My first had been at the age of 10/11.
} 
Her mission was set in stone. She would time the music to stop for her Dad's arrival home 30 minutes later. She would go for a quick walk before lunch, then would come back to eat a bowl of vegetable soup, one slice of brown bread with a thin spread of butter and some sardines or lean meat. One cup of tea.

Afternoon. More skipping. Reading about the camps. Her Dad would go for a walk. She would dance to the same song over and over for an hour. Read more about the camps. Always looking out the same window. The same grandfather clock chiming. The same copy of that grey Lowry painting hanging on the wall. All static. Nothing moving.

She would wait for dinner.

Dinner. Strict. Watching some TV with Mum. Dad gone out for a walk. Mum still watching TV but she can get away with dancing in the other room.

'Do not disturb me,' she says.

That same song. That same routine. Some ginger fizz cordial as a treat.

'Why doesn't she get a job,' Dad asks her Mum.

About six weeks later, the weight is all off, with interest. Superficially she feels better. Her life has the general feeling of: 'I can do what I want. I don't have to do anything anyone tells me anymore.'

She went to Auschwitz with her Dad. She felt like she had lived there all her life.

Traumatised by the camp. Traumatised by her history. Traumatised that she could conflate her history with those who survived the camp. How morbid her life had become, as she controlled her body under a patriarchal gaze.

'I got life.' More like 'I got death.' 'Arbeit macht frei' - that deathly reveille.

But at least when she played at that orchestra concert a family friend asked: 'Is your daughter that thin girl there?'

'Yes,' her Dad had said.

On the car journey home she asked her Mum if she looked better now:

'Yes, you do,' she said, 'although you never looked bad.' 
The car engine churned on, the only sign of life. All was static. All was quiet. The thoughts darted in her head.

She continued her death dance until the very end.

I reflect: This scene brings tears to my eyes. Aged 19, I dance alone in my family home, at the service of patriarchy. It is notable that I use the word 'utopia' to describe the world that I had built up around me. Thomas More ([1516] 1905) first coined the term to describe an imaginary community with desirable qualities. Yet, in this scene, utopia begins to verge on dystopia. While I romanticise Music as my saviour from depression, in reality it was just part of an armoury of identities I put forward to appear in control. Like any dictatorship, political or personal, what lay beneath was far from rosy. I grasped at what I could control: my weight.

My anorexic flatmate and the suffering of concentration camps, which Mbembe $(2003,12)$ describes as 'the absolute power of the negative,' act as spectres in this scene. ${ }^{16}$ Concentration camp prisoners were forced to listen to patriotic music. Likewise, I repeatedly play a song about life, moving to it with the motions of an automaton. At this time, I had become obsessed with the Holocaust and the plight of existence. I was on the side of death, especially after I visited Auschwitz with my father that summer. While my experiences could in no way be conflated with the mass suffering of Auschwitz inmates, in my head everything had got mixed up.

The childhood home is central to this scene. As Reavey (2010) writes, spaces are 'central to how the ongoing flow of memory and agency is constituted and experienced by individuals in their practice of memorial self-interpretation' (ibid., 314). Agency is 'diverse and multiple' (ibid.) and influenced by the social and political structures of society. Reavey (ibid., 317) invokes the figure of Primo Levi, who I reference in my narrative, as a person who troubles a linear version of agency. Through holding to simple everyday acts, Levi survives Auschwitz.

\footnotetext{
16 Mbembe draws on this description in relation to Arendt's ([1951] 1966: 444) musings in The Origins of Totalitarianism.
} 
Yet, he is aware of his conformity with the Nazi regime, a past that puts an unbearable weight on his existence. In 1987, Levi committed suicide. Agency is an ambivalent site.

Rethinking my reading of Levi's work at the time this scene took place, I realise that I was questioning whether I could really be called 'a legitimate victim' (Reavey 2010, 317), since I was never physically or sexually abused. Yet, the sense of distress I felt, and still do, is massive. I was brought up to feel there was a 'safe' inside space, largely based around the bourgeois family home, which I inhabited unquestionably. Yet, as Latour (2005) attests, the family home is a space where secrets are hidden and boundaries exist in and between certain family members, reinforced by family rituals.

I found myself rethinking the dominance of my father as I read Ahmed's (2006) work on queer phenomenology. Ahmed's association of the family with the body of the father is convincing. In this configuration, '...to be "in line" is to direct one's desires toward marriage and reproduction; to direct one's desires toward the reproduction of the family line' (ibid., 74). Perhaps a large part of my reluctance towards romantic relations with either sex is that romantic relations with men seem to conform to my Dad's occasional comments that start with 'and when you meet a nice man and get married...' Furthermore, romantic relations with women, which I am only now beginning to explore, feel like a source of shame that I have to hide from the family (i.e. - my father). My father was both too emotionally distant and too closely attached to my siblings and me. He often invaded our space through his thoughts, actions and words, as in this scene, when I stop dancing to time with his arrival home. Yet, the truth remains that I love my Dad perhaps more than anybody else in the world.

Likewise, I cannot fully blame my mother, for her mother made her feel bodily shame. As Orbach (2009) reminds us, female body hatred is a trans-generational process, which mothers pass down to their daughters. Yet, I argue that this is not the fault of mothers alone. It is a greater structural problem that resonates within our society. Furthermore, I extend Allegranti's (2011) criticism of 
Orbach's (2006) work, which asserts that Orbach's position too easily accepts that our early experiences fix our relationship with our bodies. As Allegranti $(2011,32)$ argues, both our brain's plasticity, and the structural subjective changes wrought by mutual recognition in the process of expressive movement, can be vital to this transformation. One can transform and overcome the limitations of a formerly despised body. Yet, in this scene I was still left with the dead weight of my mother's commentary. I ask her if I look 'better' and she responds: 'Yes, you do....' I am testing her and she has failed.

Although this scene demonstrates a primary vulnerability, it could be read in terms of a stirring sense of agency. By actively finding moments where I can move, I am beginning to challenge the stasis of my body. I realise that the intent behind my movement is not agentic. I am revealing 'a capacity to act,' yet have not quite reached 'a felt sense of action' (Reavey 2010, 315). Yet, this scene propels me towards the boundaries I need to seek between myself and the family home. While the deathly living room where I dance is central to the unfolding of this scene, it also makes me realise the need for gaining a safe space for collective enjoyment. When I go home now, I practice my Zumba routines in the very same space while imagining the collective spirit of multiple Zumba communities. Through my alternative practices, I highlight 'space as an active contributor to the movement between past and present' (ibid., 325).

In the final scene of this act, I highlight a sense of vulnerability within public space. Significantly, this scene takes place in London, in the years following my move from Ireland. I introduce myself as the fictional character, 'the girl in the navy blue dress,' which references a dress that I have owned since the age of 17 , and which I happened to be wearing during many transformative experiences. This image is carried into act 2 , showing how objects can create a thread that enables transformation.

\section{Scene 3: June 2012 - The Postfeminist Blues}

[Enter the girl in the navy blue dress, a group of her male friends and a lecherous oaf. This scene took place approximately two months before the girl came to asexuality] 
A girl in a navy blue dress

Stands poised and elegant.

Her cheeks aglow

Post Zumba exertions,

Her body toned and tanned

From the spell of good weather.

The dress's V-shaped backline nips in at the waist.

Tied with a blue velvet ribbon

Highlighting a chiselled form.

The skirt's flowing fabric dips at the back.

Her brown leather wedges add two inches.

She stands tall.

As tall as her male friends she stands at the bar.

She's on level footing now, her shoes add leverage.

'How tall are you?' one of them asks.

She tells the truth.

The wedges add two inches

Nothing more, nothing less.

To another bar they go.

Greeted by the jeers she had feared.

'Can I sleep with your woman,' he asks the male friends

Who stand on not knowing what to say.

The girl cannot speak.

Shock blocks the words from escaping her throat.

'Can I just say you're the most beautiful woman I've ever seen...

In this bar,' he leers.

She sits and rants.

'The Ryanair of the man world,' she attests.

One male friend takes pity.

He goes to the leering stranger and says, 'Apologise.'

'No,' he replies with beer on his breath and a cheeky grin on his face.

'She should be flattered, so fuck off.'

The girl sits in silence, shocked but spoken for.

The prick eventually comes around.

'I apologise,' he offers.

'You should be flattered though.'

The girl loses the rag.

'Don't you dare speak to another woman like that.

I'm not a piece of meat, I'm not a tool

Don't you dare.'

The male friends sit on in silence.

'But he apologised, I suppose,' one of them tries. 
The girl retreats to the toilets

Standing tall,

Strutting her stuff

As if on a catwalk

But for whom and for what?

She's spoken for as she passes by in his gaze.

Closing time and they leave the bar.

Male friends offer to walk her to her bus stop.

'No, I'm walking home.'

The words leave her lips before she can think.

'Are you sure you'll be safe?'

'Just leave me go'...

She turns and walks away.

3am and the walk home doesn't clear her head.

Her iPod on full blast, she hears a voice behind her

A male voice

'Marry me.'

She quickens her pace, her navy blue dress flapping.

Two inches taller but feeling small.

Alone in her room

A young woman sits small

Crying in the dark.

Capable of speech

Yet spoken for.

She is speechless.

And the tears flow.

If only she could speak.

She can speak...

I reflect: This scene feels like a rite of passage. Van Gennep ([1909] 1960) first coined the term to denote a significant life event, implying a transition from one stage to another and a shift in roles. Yet, his theories assume a linear life course and reduce asexuality to an immaturity narrative. He asserts that rites of passage mark a 'separation from the asexual world,' which lead one 'into the world of sexuality (ibid., 67). An alternative vision needs to be developed, which recognises that rites of passage are lived in time and space, where transformation need not be in the realm of genital sexuality. As Kenworthy Teather $(1999,9)$ asserts, rites of passage are rather related to 'what one's body will permit (or what the individual chooses to permit) and the decisions and challenges one feels motivated to follow through.' Thus, rites of passage are not 
just imposed by social institutions, but are influenced by human agency within space. Indeed, as this scene shows, a rite of passage can enable a transition to asexuality as a dance of female agency.

In the scene, I am enjoying an evening with male friends. I am aware of the power dynamics that go with my role as a solo female within a male collective. My brown wedges enable me to feel a sense of power. Yet, when faced with the misogyny of the lecherous oaf, who reduces me to an object of exchange, this is stripped away. While one of my male friends speaks up for me and asks the man to apologise, I ultimately feel spoken for.

Looking back on this scene, what strikes me most about its violence is how the oaf suppressed my movement. I feel like a doll, as he asks my friends: 'Can I sleep with your woman?' My small act of resistance comes when I actively choose to walk home at 3am, thus going beyond the constraints being imposed on my body. 'Just leave me go...' These words are a powerful manifestation of what Austin (1962) describes as speech acts, where words can simultaneously perform actions. I ask both the perpetrator and my male friends to respect my need for ecstatic movement.

This scene begins a process, which would continue until two months later, when I went dancing with my friends in Guanabara, a Brazilian bar, to celebrate my $24^{\text {th }}$ birthday. I was wearing a highly feminine turquoise and pink floral dress. I still felt like the doll from the night of the Postfeminist Blues. Yet, something was transforming within me. The next day, I first heard the word 'asexual,' in my head. It thus took an imaginary Latin utopia to seal my discovery of asexuality. Yet, as the next act will show, lived experiences of travel to and from Latin America and Zumba enabled my transformation.

\section{Act 2: Identities in flux}

\section{Scene 1: November 2014 - Dancing at the edge of sea and sky} [Enter the girl in the navy blue dress and $M$, a Puerto Rican waiter. It all started with a conference in San Juan, Puerto Rico, where she was presenting a paper 
titled: 'Beating the Postfeminist Blues? Female asexual identities and the limits of transgression.' What ensued was not wholly as expected, as she met a certain Puerto Rican waiter in a café she frequented...]

You slipped me a note

In with my receipt.

Behind my coffee cup

I rejoiced.

The creamy incandescence

Of my café con leche

Could scarcely conceal

My joy,

As I drank in my expectations

Of you,

Asking me, did I have any plans

For my last night in old San Juan?

By cobblestones and candlelight

We revelled in words and song

At the poetry passage,

Sipping craft beer

As you translated any Spanish

That I could not comprehend

As I attempted to learn our

Common language.

Our chatter became incessant Amongst the constant calls of 'Wepa.'17

You took me to a bar

On San Sebastian

Where you taught me

Spanish on a napkin

And I resurrected my Irish.

'You have beautiful eyes.'

'Tienes hermosos ojos.'

You led

Me to the edge.

To the rolling waves and

Rustling planes

Of the ancient fort

El Morro.

A dark sky dotted with little

Flecks of gold.

I saw your soul.

You told me you felt like kissing me.

17 This is a phrase of jubilation used amongst Hispanics, especially Puerto Ricans. 
I told you

'I'd say go for it.'

I did not think.

I relented.

We reached each other

And connected

As the boundaries of sea

And sky became blurred.

We revelled in each others' spirits.

In each others' tongues.

Tongues in flames.

A fort on fire.

Limbs of the licking flame

Reaching and folding.

A bonfire of souls,

Feeling each others'

Boundaries.

Going too far...

Yes, too far.

And retreating.

A calming moment.

Gentle caresses.

A light rain comes.

I leave wet and flushed.

I will not see you

Anytime soon.

Back in New York

I viewed Mark Rothko's

'Slow swirl at the edge of the sea.' 18

Two painted creatures

Dance between sea and sky.

I remembered you

And knew that nothing could

Match the brilliance

Of our meeting

In each others' embrace.

The memory of your touch.

But that girl in a navy blue dress

Nipped in at the waist

Revealing a chiselled form

Had been awakened that night

The navy blue dress

18 This reference alludes to Rothko's 1944 painting, which is on show at the Museum of Modern Art, New York. Rothko, M 1944. Slow Swirl at the Edge of Sea and Sky [painting]. New York: Museum of Modern Art. Available at: http://www.moma.org/collection/works/79691 [last accessed 13 July 2016]. 
From the scene of the postfeminist blues.

\section{Scene 2: Back on land}

[Enter the girl in the navy blue dress, out of costume]

Back to this puppetry display.

I viewed the scene anew.

You kissed me.

You pulled at my hair

You tugged at my

Navy blue dress

And its gathering ribbon

But I was afraid

That you would tear

My delicate ribbon

And cherished opal chain

Opulently set

On this golden statuette of submission,

As all the time the phrases

'Chaotic sexuality' and

'A girl is a half-formed thing' 19

Swirled round and round in my head.

The wedges (cream this time)

Put her on a podium.

Her

She

But also I.

And also you.

You.

I drank in you.

You drank in me

And ate me up

On a golden spoon.

A frozen statuette

Gleaming like a beacon.

You asked me if I had

Ever had a boyfriend.

I said 'No'

You asked

'Why not?'

19 This reference alludes to Eimear McBride's (2014) award-winning novel, A Girl is a Halfformed Thing. The novel provides an insight into the turbulent sexuality of a vulnerable young woman who experienced sexual abuse during childhood, and her enduring relationship with her ill brother. 
I said

I'm incredibly independent...

You told me that I was so beautiful

That I had an amazing body

That you were aroused

And that you felt like getting more mischievous

As your hand crept further up my right thigh.

I froze and you sensed my discomfort.

You retreated.

I remained silent

I did not feel in control

But somehow I was enjoying it.

Dispersed from the convent

Evicted at this early hour.

Drinking in the night sky

And the rolling waves.

Intoxicated by another,

To return many moons later

Wet and refreshed

Having drunk not from the Holy Water font

But the elixir of desire

A desire consuming

Yet contained

Not desiring full consummation.

That girl

Half way between

A courtesan

And the aloof woman of

Klimt's 'The Kiss.' 20

A girl relenting

Allowing herself to be kissed.

Frozen in a moment

Yet simultaneously consumed.

Surrounded by gold leaf stars -

A glittering golden statuette

In those night-time revellings.

\footnotetext{
20 This reference alludes to Klimt's infamous (1907-1908) painting, The Kiss, whose content has been the source of much scholarly debate. It is often asked if the woman in the painting is actually enjoying the kiss, as she appears to pull away from her lover. This, of course, is an open question. The painting is rich in symbolism, with the male covered in rectangles, a mythical symbol of masculinity, and the woman in circles, a symbol of femininity. The woman is rooted to the earth, a connection that is also often made in mythology. The painting is covered in gold leaf, which was also common in Medieval spiritual painting. In the scene I narrate here, the Klimt reference relates to the girl in the navy blue dress's conflicting feelings surrounding the kiss, but also to the fact that she was wearing dangling gold earrings with many strands while the scene was happening. Klimt, G. 1907-1908. The Kiss [painting]. The Belvedere Museum, Vienna. Available at: http://www.klimt.com/en/gallery/women.html [last accessed 13 July 2016].
} 
I Reflect: In the months prior to my Circum-Caribbean navigation between New York and Puerto Rico, I had experienced distress with regards to my asexuality. Researching the topic daily was making me feel incredibly vulnerable. I had reached an impasse. I was not sure if the pain of researching the topic was worth it. Therefore, this trip was a lifeline.

Having enjoyed the grid-like linearity of New York, I left for San Juan, Puerto Rico. I gave my paper on the genealogy of female (a)sexualities, where I invoked such characters as the frigid woman and the postfeminist single woman. Yet, I attended very little of the conference. I wanted to distance myself from asexuality and from the need for verbal interaction about my academic work.

What strikes me about the first scene is that it follows a conventional romantic narrative, to an excessive extent. There is the note written on the back of the receipt, the romantic poetry café, the bar where we flirt and the ultimate climactic scene at the fort. These spatial markers set the scene. In my normal life, I would have felt nauseous at their hyper-romanticism. Yet, in those liminal moments, I feel like going with the flow.

As Ahmed (2006) highlights, the role of the body in disorientation plays a huge role in how perceptions of our sexual orientations may shift over time. We may find ourselves re-oriented in stability or reaching out for something that we simply cannot grasp: "The point is what we do with such moments of disorientation, as well as what such moments can do - whether they can offer us the hope of new directions, and whether new directions are reason enough for hope' (ibid., 158). Indeed, my experiences offer me hope. They resonate with Ahmed's (ibid., 171) assertion that it is not so much a question of 'what is a queer orientation, but how we are orientated toward queer moments when objects slip.' This is a very queer moment indeed, where I see myself dancing at the edge 
of sea and sky. ${ }^{21}$ The images in the scene evoke a sense of movement. Yet, the scene also concerns itself with boundaries: both the need to establish safe boundaries and to become enmeshed with another, where linear time is forgotten and transformation is key to the process itself. This liminality is produced by both place and the 'carnivalesque loss of identity' (Shields 1991, 97). 22

This scene brought me to a more creative conception of asexuality, through the process that Braidotti $(2006,172)$ calls 'multi-layered levels of affectivity,' which are 'the building blocks for creative transpositions' and 'mark heightened levels of awareness and receptivity.' It was pivotal in my trajectory, for it challenged the internalised view of myself as a female 'asexual.' Yet, it also made me experience a sense of loss for something intangible, which speaks to Butler's $(2004,18)$ account of 'the transformative effect of loss.' My pining was for a moment of deep closeness with another human being. This is perhaps why viewing Rothko's painting, Slow Swirl at the edge of sea and sky, on my return visit to New York had such a profound effect on me. As Butler (2004) asserts, loss is encountered in moments where we inhabit a space between self and world. In the process, we become 'undone' by another, 'by the touch, by the scent, by the feel, by the prospect of the touch, by the memory of the feel' (ibid., 19). This is strongly reflected in my reference to 'the memory of your touch.'

Act 2 scene 1 reflects an awareness of my (a)sexuality not as cold, but as sensuous, relational and dancing. Yet, in scene 2, I begin to question the romantic and sexual scripts that dance under its surface. I unearth a feeling of being colonised against my will, which exists in tension with the tenderness I evoke in scene 1 . Movement is central to this questioning. It is suggested in the images of 'chaotic sexuality' that 'swirled round and round in my head.' My

\footnotetext{
${ }^{21}$ My experiences connect with Winchester, McGuirk and Everett's (1999) work, which explores the transforming identities of teenagers during Schoolies Week, on the Gold Coast of Australia. The authors narrate how this was a transitional phase, 'where identities in the process of transformation become fluid' (ibid., 60). Significantly, they assert that this transformation had a spatial dimension, since it took place on a piece of land overlooking a vast ocean, much like my scene at El Morro.

22 This invokes Bakhtin's (1941) notion of 'the carnivalesque' in literature.
} 
further reference to 'the convent' both evokes the ex-convent hotel I was staying in, in Old San Juan, and my past life as a Catholic. Yet, I experience a desire 'not desiring full consummation,' which challenges the assumption that heterosexual sex always ends in penetration.

It is also significant that the scene subsequently conjures up the image of Klimt's painting, The Kiss, which embodies both movement and stasis. The woman in the painting, being kissed by a man, appears rigid, yet is surrounded by moving spirals. In resonance with this, in the final lines of this scene, I am attempting to explore what my shifting relationship with space is. In the El Morro scene, was I really in movement? All I can say is that the scene enabled transformation. I came to autoeroticism in the days and months following the encounter, as a means of recreating its sensuousness. Puerto Rico became a recognisable location on my everyday mental horizons - partially fantasy and partially reality which enriched my developing conception of intimacy. While these scenes can never be physically recreated, I reach a sense of inner ecstasy any time I reimagine them, and this is part of their power.

\section{Scene 3: Zumba: Becoming my dance}

[Enter the girl in the navy blue dress, dancing herself to life]

When she danced It was as if she was dancing herself to death. The rhythm pulsed through her body. She did not need alcohol or drugs. The music was her drug of choice, Movement its articulatory gesture.

Sexless

Genderless

Just pure movement

Pure joy

Pure energy

Pure ecstasy

It was if she was in the throws of passion But this was her way of expressing it. Her body working to its full capacity Moving with conviction and rhythm, Admired for its strength Dancing itself a heavenly death. 
I Reflect: I came to Zumba in March 2012, six months after I arrived at asexuality, and became a Zumba teacher in July 2015. Zumba has supported the various shifts in my subjectivity. It is an encounter with my body within time and space, a manifestation of what Fraleigh $(1987,183)$ calls 'moving timespace.' It exists outside the normal flow of time. Ordinarily, I relate to Young's ([1980] 2005, 38) conception of 'inhibited intentionality,' where my body feels constrained within space, and fears spontaneous movement. However, when I Zumba, I move with what Fraleigh $(1987,19)$ calls 'intentional motion.'

When I Zumba, I throw my body into space. There is no need for external objects. Part of the reason I used to dread sports at school was because of a fear of objects: that moving ball that sometimes hit me in the face and the possibility of once again 'throwing like a girl,' to use the title of Young's ([1980] 2005) essay. Another tragic-comic example was when I fell off a spacehopper at a school sports day and hit my head off a wall. I felt like my body had failed me and it took great conviction to believe in it again. In fact, I tried one Zumba class in Ireland a few years before I moved to London and hated it. I felt horribly uncoordinated and inhibited, as if this exuberant style was not for me. Yet, within three weeks of starting Zumba classes in London, I became obsessed. My inhibitions fled without me even willing them away. My love grew, under the tutelage of three inspiring teachers, all of whom I deeply admire and who are equally inspired by my energy. ${ }^{23}$

While sometimes I feel like an imposter - a dancer with no training and a fitness instructor who still fears going near a spacehopper - I am becoming the dancer I never was. I now teach others Zumba and it makes me realise, in the spirit of Jonas's (1966) work, that no matter how vulnerable the label of 'asexuality'

\footnotetext{
23 The first is an elegant Chilean dancer, who gave me private dance lessons in exchange for teaching her son piano. She once told me that when she saw me moving it made her 'happy.' The second is a radiant Rwandan woman, full of energy and positivity. I will never forget Tuesday night and Saturday afternoon Zumba classes with her, wonderful dots of intensity that punctuated my week. The sense of collective joy always radiated in the room. The third is a Hispanic/ creole woman, whose style has an urban edge. Her strength and passion are admirable.
} 
makes me feel in the world, there is always possible freedom. I make my mark in time and space with intentional movement, leading and motivating others, as part of an inclusive global Zumba community. I have come to what Fraleigh $(1987,27)$ calls a 'whole-body consciousness.' Dance is a form of knowledge for me, both lived and thought through the body. Like the possibilities of different choreographies, I find the actualisation of many possible selves in Zumba. I carry Zumba with me in all my endeavours. Zumba's marketing slogan, 'Let it move you,' is not just a marketing ploy. Yet, to be more specific, I do as Fraleigh (ibid., 18) suggests: 'I move myself.'

\section{Coda: Reflective Notes}

... What we most truly desire is to surround the self, preferably in the agony of ecstasy, thus choosing our own way of disappearing, our way of dying to and as our self (Braidotti 2006, 252).

I end with a coda, which evokes Braidotti's (ibid.) nomadic remembering as: 'a quest for temporary moments when a balance can be sustained, before the forces dissolve again and move on.' In this scene, I look back to the origins of my shifting view of female (a)sexualities, as embodied in the figure of the bomba ${ }^{24}$ statuette, a symbol of Puerto Rican national culture. I have internalised the spirit of Afro-diasporic rhythms and it acts as a life force as I walk through the streets. Yet, by the end of the scene, I forget the origins of my transformation in a happy dissolution. By reaching a sense of oneness with sea and sky, I achieve the process of 'becoming-imperceptible,' as conceptualised by Deleuze and Guattari ([1980] 2004, 308-311) and which Braidotti $(2006,154)$ describes as 'the

\footnotetext{
24 Bomba is a dance style native to Puerto Rico, which demonstrates the influences of African, Spanish and Taíno cultures. It originated amongst slaves on the sugar plantations in the nineteenth century. As noted by Duany (1992), after 1815, Haitian influences also entered the genre, when a decree under the Spanish Crown allowed Haitians entry into Cuba and Puerto Rico. The dance features two or three drums, with one improvising and the other forming the bass. The melody is antiphonal and repetitive, featuring nonsense syllables that follow the rhythm. Storm Roberts (1992) argues that bomba is more African-influenced than any of the Cuban genres. Indeed, with its combination of African rhythms, drumming and dancing, many Puerto Ricans connected it with vaudun witchcraft. Yet, as my bomba statuettes stand suspended in motion, the witch is imbued with an empowering rhythm.
} 
eruption of events that construct sustainable futures.' This is not a hopeless selfdissolution. Instead, I demonstrate my death to any notions of identity.

CODA

Moving on

[Enter the enlightened me]

Swirl

Turn

Let loneliness live

Then constantly die.

Let me allow myself to become

That hazy figure

That bomba statuette

Silhouetted

And projected in the light

From the hallway.

My table is her stage.

My pen abets the flow of her skirt.

The creases that propel her

Into movement.

I am the dancer I never was.

I dance through the streets.

You dance with me too.

The people move between us.

I weave in and out

I'm swimming

Synchronised.

Poised and pirouetting,

I rush to the beat of

London time.

This is the only way

Forward-

To move

To swirl

To dance.

I lose myself.

A happy dissolution

[Vivir mi vida\}.

Happy is the day

That I forget

Where I gave birth

To myself

Anew.

The past is irreverent. 
The past is a morgue.

Full of corpses

I wish not to resurrect.

People I once thought

Myself to be.

Whilst failing to realise

That I am not myself alone.

Who am I without others?

So here, yes,

On this crowded street

Dance with me

In this moment

Where a bud

Blossoms into a flower.

Slowly slowly

Time goes heavy.

The past dissipates.

I am at one with sea and sky.

\section{Conclusion:}

Life writing engages with the nuances of human experience, through autobiography, diaries, personal letters and testimonies, amongst other genres (McCooey 2017). As a discipline, it has become increasingly influenced by insights from postcolonial and feminist theory. Yet, as I have argued, it tends to support a linear narrative, which needs to be transcended by focusing on transformative moments. As Winterson (2014, vii-viii) asserts in her introduction to Sexing the Cherry, 'the string is the narrative but the spaces are what matters.' This is particularly relevant to the exploration of queer sexualities, which refer to 'nonnormative logics and organizations of community, sexual identity, embodiment, and activity in space and time' (Halberstam 2005, 6). In this way, we should focus on the 'queer moments when objects slip' (Ahmed 2006, 171), so that we can parody the limitations placed on human 
experience, and work towards a more ethical relationship between all human beings. As Butler $(1990,1993)$ argues, performance is a useful mechanism for engaging with this work, as it enables us to communicate identities, and to articulate the narratives of those otherwise excluded from public discourses.

In this piece of 'me-search' (Nguyen 2015) and performance autoethnography (Spry 2001), I have evoked the lost narrative of the female 'asexual' through a combination of theory and personal narrative, challenged the fixity of sexual orientation categories, highlighted the inadequacy of identity categories in capturing the complexities of lived experience, and narrated moments of becoming in my trajectory where identities were in flux. Through my poetic use of language, I have sought to convey how bodily movement can create embodied knowledge. It is hoped that this approach will both encourage stylistic creativity in future research and allow the lived experiences of the body to become more central to the research process.

\section{Acknowledgements}

I wish to thank my PhD supervisors at King's College London, Professor Anna Reading and Professor Ananya Kabir for their continuing insights and the ESRC for funding my PhD. I also deeply appreciate the trilogy of Zumba teachers, Alejandra Loreto Quintana Alvárez, Charlotte Kabagwera and María Elena Venthoye Devora, who inspired me to become a Zumba Fitness instructor. Finally, I wish to thank all the other Zumba Fitness instructors worldwide, who welcome me as part of our global Zumba community. 


\section{Notes on contributor}

Aoife Sadlier completed her PhD in the Department of Culture, Media and Creative Industries, King's College London, in 2017. Her research explored the junctures and disjunctures between representations of female (a)sexualities and the lived experiences of women, and in particular examined the role that collective movement practices play in women's shifting (a)sexualities. Aoife currently works as a Research Associate on the 'New Development Frontiers? The Role of Youth, Sport and Cultural Interventions' project at Loughborough University. She also teaches the global Latin dance fitness programme, Zumba Fitness, in various gyms and community settings.

\section{References}

Ahmed, Sara. 2006. Queer Phenomenology: Orientations, Objects, Others. Durham, NC and London: Duke University Press.

Allegranti, Beatrice. 2011. Embodied Performances: sexuality, gender, bodies. New York: Palgrave Macmillan.

Arendt, Hannah. [1951] 1966. The Origins of Totalitarianism. New York: Harvest.

Austin, J.L. 1962. How To Do Things With Words. Oxford: Clarendon Press.

Bakhtin, Mikhail 1941. Rabelais and his world. Bloomington: Indiana University Press. 
Bogaert, A.F. 2004. "Asexuality: Prevalence and Associated Factors in a National Probability Sample." The Journal of Sex Research 41 (3): 279-287.

http://www.jstor.org/stable/4423784.

Braidotti, Rosi. 2006. Transpositions: On Nomadic Ethics. Cambridge: Polity.

Butler, Judith. 1990. Gender trouble: Feminism and the subversion of identity.

Reprinted 2006. New York and Abingdon: Routledge.

Butler, Judith. 1993. Bodies that matter: On the discursive limits of 'sex.' New York: Routledge.

Butler, Judith. 2004. Undoing Gender. London: Routledge.

Cerankowski, Karli and Megan Milks., eds. 2014. Asexualities: Feminist and Queer Perspectives. New York and Oxford: Routledge.

Cixous, Hélène and Clément, Catherine. 1986. The Newly Born Woman.

Minneapolis, MN: University of Minnesota Press.

Deleuze, Gilles and Guattari, Félix. 1980. A Thousand Plateaus: Capitalism and Schizophrenia. Translated from French, with an introduction by Brian Massumi 2004. London and New York: Continuum.

Duany, Jorge. 1992. "Popular Music in Puerto Rico: Toward An Anthropology of Salsa." In Salsiology: Afro-Cuban Music and the Evolution of Salsa in New York City, 
edited by Vernon W. Boggs, 69-90. New York, Westport (CN), California and London: Greenwood Press.

Elias, Ana Sofia, Gill, Rosalind and Scharff, Christina, eds. 2017. Aesthetic labour: Rethinking Beauty Politics in Neoliberalism. Basingstoke: Palgrave Macmillan. Fraleigh, S.H. (1987) 1996. Dance and the lived body: A Descriptive Aesthetics. Reprint, Pittsburgh, PA: University of Pittsburgh Press.

Gill, Rosalind and Christina Scharff, eds. 2011. New Femininities: Postfeminism, Neoliberalism and Subjectivity. London: Palgrave Macmillan.

Gochros, Harvey L., Gochros, Jean S. and Joel Fischer eds. 1986. Helping the Sexually Oppressed. New Jersey, NJ: Prentice-Hall.

Halberstam, Jack. 2005. In a Queer Time and Place: Transgender Bodies, Subcultural Lives. New York and London: New York University Press.

Johnson, Myra T. 1977. “Asexual and Autoerotic Women: Two Invisible Groups.” In The Sexually Oppressed, edited by Harvey L. Gochros and Jean S. Gochros, 96109. New York: Associated Press.

Jonas, Hans. 1966. The Phenomenon of Life: Toward a Philosophical Biology. New York: Harper and Row.

Kabir, Ananya Jahanara. forthcoming. Zumba as a global phenomenon. 
Kenworthy Teather, Elizabeth, ed. 1999. Embodied Geographies: Spaces, Bodies and Rites of Passage. London and New York: Routledge.

Latour, Bruno. 2005. Reassembling the Social: An Introduction to Actor-Network Theory. Oxford: Oxford University Press.

Levi, Primo. 1947. If This Is A Man/ The Truce. Translated by Stuart Woolf, 2003. London: Abacus.

Mbembe, Achille. 2003. “Necropolitics.” Translated from French by Libby Meintjes 2003. Public Culture 15 (1): 11-40. doi: 10.1215/08992363-15-.1-11

McBride, Eimear. 2014. A girl is a Half-formed Thing. London: Faber and Faber.

McCooey, David. 2017. "The Limits of Life Writing." Life Writing, 14 (3): 277-280. doi: DOI: $10.1080 / 14484528.2017 .1338910$

More, Thomas. [1516] 1905. Utopia. London: Cassell and Co.

Nguyen, Vinh. 2015. “Me-search, Hauntings, and Critical Distance.” Life Writing 12 (4): 467-477. doi: 10.1080/14484528.2014.915285

Orbach, Susie. 2006. "How Can We Have a Body? Desires and Corporeality."

Studies in Gender and Sexuality, 7 (1): 89-111. doi:

10.2513/s15240657sgs0701_9 
Orbach, Susie. 2009. Bodies. London: Profile Books.

Reavey, Paula. 2010. “Spatial markings: Memory, agency and child sexual abuse.” Memory Studies 3 (4): 314-329. doi: 10.1177/1750698010370035

Shields, Rob 1991. "Ritual pleasures of a seaside resort: liminality, carnivalesque, and dirty weekends." In Places on the Margin: Alternative Geographies of Modernity, edited by Rob Shields, 73-116. London: Routledge.

Simone, Nina. 1968. Ain't Got No, I Got Life. In N. Simone, 1968. 'Nuff Said! Compact disc. New York: RCA Studios.

Spry, Tami. 2001. "Performing Autoethnography: An Embodied Methodological Praxis." Qualitative Inquiry, 7 (6): 706-732. doi: https://doi.org/10.1177/107780040100700605

Storm Roberts, John. 1992. “The Roots.” In Salsiology: Afro-Cuban Music and the Evolution of Salsa in New York City, edited by Vernon W. Boggs, 7-22. New York, Westport (CT), California and London: Greenwood Press.

Tchaikovsky, Pyotr. 1875. Swan Lake. Musical score. New York: Kalmus. 
Van Gennep, Arnold. (1909). The Rites of Passage. Translated from French by

Monika B. Vizedom and Gabrielle L. Caffee (1960). London: Routledge and Kegan Paul.

Winchester, Hilary P.M., Pauline M. McGuirk, and Katherine Everett. 1999. "Schoolies Week as a Rite of Passage: A study of celebration and control." Embodied Geographies: Spaces, Bodies and Rites of Passage, edited by Elizabeth Kenworthy Teather, 59-77. London and New York: Routledge.

Winterson, Jeanette. 2014. “Introduction.” In Sexing The Cherry (1989),vii-xi. London: Vintage Books.

Young, Iris Marion. 2005. “Throwing Like A Girl: A Phenomenology of Feminine Body Comportment, Motility and spatiality." In On Female Body Experience: "Throwing like a girl" and other essays, 137-156. Oxford: Oxford University Press. Originally published in 1980 in Human Studies, 3 (2): 137-156. doi: http://www.jstor.org/stable/20008753. 